\title{
Information System for Selection of Production Line for Plastic Item Injection Machine Number A36 Using Priority Scheduling Method
}

Sistem Informasi Pemilihan Urutan Produksi Barang Plastik Injeksi Mesin Nomor A36 Dengan Metode Priority Schedulling

Received: 8 June 2020

Accepted:

29 June 2020

Published:

19 August 2020

\author{
1*Muchamad Dani Chairudin, ${ }^{2}$ Novita Br Ginting, ${ }^{3}$ Hersanto \\ Fajri \\ ${ }^{1,2,3}$ Sistem Informasi, Universitas Ibn Khaldun Bogor \\ ${ }^{1,2,3}$ Bogor, Indonesia \\ E-mail:1'daniudin.du@gmail.com, ${ }^{2}$ novitawahab@uika-bogor.ac.id, \\ hersanto.fajri@gmail.com
}

*Corresponding Author

\begin{abstract}
A PT. Astra Components Indonesia manufactures injection plastic goods to be sent to customers, in the production process the machines used are capable of producing several types of injection plastic goods, so that products can be provided regularly and there is a process of changing products or better known as the Dandory process. Found an obstacle that is an error in determining the order of dandory for production. Consequently, the condition of goods in the warehouse is irregular. It is detrimental to the company with the time, material and labour that has been expended for production so that an Information System is needed to determine the priority schedule for the replacement of injection plastic goods in this study taking the case at machine number A36. The system development uses the Waterfall method; the system description will be described by the Unified Modeling Language Modeling (UML) method. Data collection is done by observing directly observing production activities in the company as well as interviews with relevant parties, and for solving problems, the system will be assisted by Priority Scheduling method. The results of the research get an information system that will provide recommendations for items that will first be produced appropriately.
\end{abstract}

Keyword-Information System, Waterfall, Priority Scheduling, Dandory, UML

Abstrak - A PT. Astra Komponen Indonesia memproduksi barang plastik injeksi yang akan dikirim ke pelanggan, dalam proses produksi mesin yang digunakan mampu menghasilkan beberapa macam tipe barang plastik injeksi, agar barang dapat produksi secara teratur dan tepat ada proses pergantian barang atau lebih dikenal dengan proses Dandory. Ditemukan kendala yaitu kesalahan menentukan urutan dandory untuk produksi, akibatnya kondisi barang di gudang tidak teratur. Hal ini merugikan perusahaan dengan waktu, material dan tenaga yang telah dikeluarkan untuk produksi sehingga dibutuhkan Sistem Informasi untuk menentukan prioritas jadwal pergantian barang plastik injeksi dalam penelitian ini mengambil kasus pada nomor mesin A36. Pengembangan sistem menggunakan metode Waterfall, gambaran sistem akan diuraikan dengan metode permodelan Unified Modeling Languange (UML). Pengumpulan data dilakukan dengan cara observasi mengamati langsung kegiatan produksi di perusahaan serta wawancara dengan pihak-pihak terkait dan untuk pemecahan masalah, sistem akan dibantu dengan metode Priority Schedulling. Hasil dari penilitian mendapatkan sistem informasi yang akan memberikan rekomendasi barang yang akan terlebih dahulu diproduksi secara tepat.

Kata Kunci-Sistem Informasi, Waterfall, Priority Scheduling, Dandory, UML 


\section{INTRODUCTION}

PT. Astra Components Indonesia as a manufacturer of finished goods in plastic injection (plastic injection) serving a variety of motor vehicle assembly companies, has a target to achieve a position as a leading parts company in Indonesia. This target can be realized with the support of many parts of it, one of which is the PC (Production Control). PC staff planned the production of 279 kinds of injection plastic goods with 130 machines available, with fewer machines available than the number of items that must be produced each day, making several devices capable of producing more than 1 type of injection plastic goods to meet the needs of the warehouse (warehouse) so that the condition of the goods is in functional status in this study taking the case of machine number A36. PC staff must be able to determine the priority of products produced with the criteria of supporting components to make the production process more effectively and efficiently to compete in the global era to manage production schedules properly.[1]

Based on direct observations to the field, the ongoing conditions of how to determine the priority of the order of goods on a machine for injection plastic production is done conventionally by looking at the data sheets and calculating the products to be produced first so that there are still problems with calculation errors due to human error; This study aims to eliminate obstacles so that the company does not experience losses [2], the method used is the priority scheduling method in preemptive because the ongoing production priorities can be replaced with other preferences of higher priority [3].

The system development method used is the waterfall method [4] with complete data prefixes that will simplify and speed up the development of the system so that this method is more suitable in this study compared to other methods such as the prototype method [5] and the spiral method [6] which takes more time because it adjusts the system to the source regularly due to the incomplete prefix data.

This research in solving the problem using the priority scheduling method is done preemptively [7] because in this study has five criteria to determine the final output and each approach can determine the priority of goods production, so that if there are criteria that are not met, then the goods will be replaced by priority with other items even though the priority of other items is higher, in contrast to cases [8] existing preferences cannot be replaced. As for other methods such as Fuzzy Tsukamoto [9], [10] and Analytic Hierarchy Process (AHP) [11], [12] but they cannot meet the needs because in this method they cannot determine the average waiting time for item replacement only to obtain a sequence production of goods only. This information system in addition to learning the order of production of goods on the machine can display the criteria that support products such as data on the availability and needs of finished goods, raw 
INTENSIF, Vol.4 No.2 August 2020

ISSN: 2580-409X (Print) / 2549-6824 (Online)

DOI: https://doi.org/10.29407/intensif.v4i2.14321

materials, packaging facilities, human resources (workforce) can be utilized by PC staff in getting information quickly and precisely.

\section{RESEARCH METHOD}

The method to be used is the waterfall method or what is often called the waterfall method is often called the classic life cycle. Starting with an analysis in the PC section through the stages of observation, interviews (review), the study of literature and analysis of the use of priority scheduling methods, then enter the design stage of the display and function of the system (design), followed by (coding) using the programming language that we use is PHP and HTML, then testing (testing) on the system meets the needs of the PPIC [8], [13], as shown in figure 1.

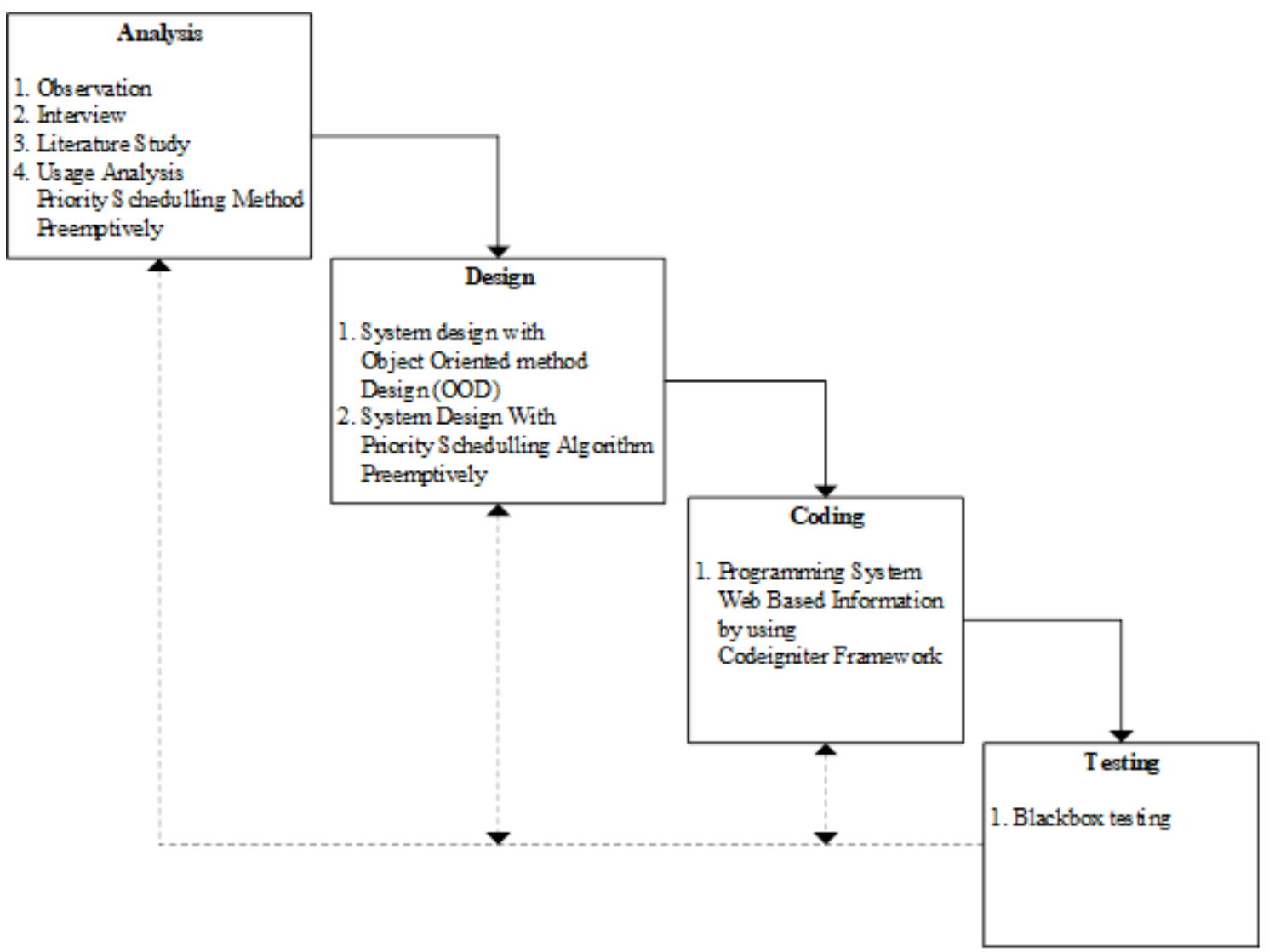

Figure 1. WATERFALL METHOD

In Figure 1, it is explained that if there are changes that are not following the needs of the user, then each stage can return to the previous step without having to repeat back to the initial stage, making this method faster than the other methods. [4], [5]. 
A. Analysis

Analyze business processes that are running, through observation and interviews as follows.

1. Observation

Observing is an activity of seeing production planning data, production achievement data, data dandory schedule and PPIC employee performance and production planning process in the injection plastic part, analyzing the right method for problems in the field in this study the technique used is the priority method preemptive scheduling.

2. Interview,

The interview is digging information from trusted sources through the conversation of two or more people by delivering several questions to PC staff as resource persons.

\section{B. Design}

At this stage, the process of translating the needs of an information system design before starting coding focuses on making data structures, software architecture, interface representations, and algorithms to be used. The system design method uses the Object-Oriented Design (OOD) method by describing the system requirements analysis into modelling design which is then poured into the Unified Modeling Language (UML) to produce documents called software requirements in the form of diagrams that will be used to carry out information system manufacturing activities. Diagrams that will be used Use Case Diagrams, Activity Diagrams, and Class Diagrams will be discussed in the next chapter.[14], [15].

\section{Programming}

In this process after the tools and materials are fulfilled, and translated into a diagram, the next step is to implement it through a coding process that uses the Microsoft Visual Code application with the PHP programming language with the help of a code igniter framework to facilitate documentation and data changes periodically, to enable recording, the system will connected to the database. The system will be implemented web-based in PT. Astra Komponen Indonesia (Tbk).[16]

D. Testing

To avoid errors (errors) when the system is used it is necessary to test the functions that have been planned by using the black box method to find out when making inputs, processes and outputs are following the planning and needs of the user [17]-[19]. 
INTENSIF, Vol.4 No.2 August 2020

ISSN: 2580-409X (Print) / 2549-6824 (Online)

DOI: https://doi.org/10.29407/intensif.v4i2.14321

\section{RESULT AND DISCUSSION}

A. Requirements Analysis

1. Calculating of Priority Scheduling Method

Analyzing existing problems and available material tools with expected results was decided to use the priority scheduling problem-solving method preemptively as an example of the case on the A36 machine following the steps in applying the priority scheduling method [7].

a. Knowing what items are filling up on the A36 machine is taken from PC staff by observing and interviewing in the field and obtained data for February 2020 called Loading vs. Capacity containing the machine number, item name, speed per hours (sph) of the machine in producing goods, the cavity is a mould of products, and the amount of assets needed for production for a month in units of pcs, this data has been translated into simple tables, such as tables 1 .

Table 1. MAChine A36 DATA TABLE

\begin{tabular}{clccr}
\hline $\begin{array}{c}\text { Machine } \\
\text { Number }\end{array}$ & \multicolumn{1}{c}{ Item Name } & SPH & Cavity & $\begin{array}{c}\text { Goods Needs } \\
\text { (pcs) }\end{array}$ \\
\hline A36 & Cover Front Lower K59J & 60 & 1 & 11662 \\
\hline A36 & Garnish Front K59A & 45 & 2 & 15339 \\
\hline A36 & Garnish Front K59A R-364R & 60 & 2 & 5563 \\
\hline A36 & Cover Center K59A & 70 & 2 & 23595 \\
\hline
\end{tabular}

In table 1, the first criterion data aims to find out the number of goods that must be produced for 1 month and the capacity of production capability with speed per hours (SPH) and the number of printed products (cavity).

b. Calculating the need for goods in units of hours is as a table 2 .

Table 2. Table Of The NeEd For The Production Of Goods In One Hour

\begin{tabular}{|c|c|c|c|c|c|c|}
\hline $\begin{array}{l}\text { Machine } \\
\text { Number }\end{array}$ & Item Name & SPH & Cavity & $\begin{array}{c}\text { February } \\
\text { Production } \\
\text { Needs } \\
(\text { Pcs })\end{array}$ & $\begin{array}{c}\text { Number } \\
\text { of } \\
\text { Working } \\
\text { Days in } \\
\text { February }\end{array}$ & $\begin{array}{c}\begin{array}{c}\text { Production } \\
\text { Requirement } \\
\text { (Hours) }\end{array} \\
\text { [product } \\
\text { needs. / (SPH } \\
\text { x Cav.)/HK] }\end{array}$ \\
\hline A36 & $\begin{array}{l}\text { Cover Front Lower } \\
\text { Assy K59J }\end{array}$ & 60 & 1 & 11,662 & 20 & 9.7 \\
\hline A36 & Garnish Front K59A & 45 & 2 & 15,339 & 20 & 8.5 \\
\hline A36 & Cover Center K59A & 60 & 2 & 5,563 & 20 & 2.3 \\
\hline A36 & $\begin{array}{l}\text { Garnish Front K59A R- } \\
\text { 364R }\end{array}$ & 70 & 2 & 23,595 & 20 & 8.4 \\
\hline
\end{tabular}


INTENSIF, Vol. No.2 August 2020

ISSN: 2580-409X (Print) / 2549-6824 (Online)

DOI: https://doi.org/10.29407/intensif.v4i2.14321

In table 2, calculate the production requirements in hours by calculating the number of production needs (pcs) divided by SPH times cavity then divided by the number of working days, the number of hours of production of each item in one day is obtained. This result will determine the initial priority sequence, as will be illustrated in table 3 .

c. Sort the initial priority based on the order of production needs in units of hours from the largest to the smallest, as illustrated in table 3 below.

Table 3. TABLE OF EARLY PRODUCTION PRIORITY

\begin{tabular}{clcc}
\hline \hline $\begin{array}{c}\text { Machine } \\
\text { Number }\end{array}$ & \multicolumn{1}{c}{ Item Name } & $\begin{array}{c}\text { Production } \\
\text { Requirement } \\
\text { (Hours) }\end{array}$ & Priority \\
\hline A36 & Cover Front Lower Assy K59J & 9.7 & 1 \\
\hline A36 & Garnish Front K59A & 8.5 & 2 \\
\hline A36 & Cover Center K59A & 2.3 & 4 \\
\hline A36 & Garnish Front K59A R-364R & 8.4 & 3 \\
\hline
\end{tabular}

Table 3 shows the initial priority sequence for production, starting from the largest to the smallest production requirements, entering the next stage.

d. The next step is to change the name of the item according to each priority order. K59J Lower Assy Front Cover becomes P1 (Priority 1), K59A Garnish Front becomes P2 (Priority 2), K59A Gar59 Front R-364R becomes P3 (Priority 3), K59A Cover Center becomes P4 (Priority 4).

e. Give a rating, and priority value of each condition of the production criteria can be seen in the table 4-8 :

Table 4. Table Of Rating \& VAlue Of Criteria Status Finish Well

\begin{tabular}{cc}
\hline \hline Rating & Value \\
\hline Minus & 3 \\
\hline Critical & 2 \\
\hline Normal & 1 \\
\hline Over & 0
\end{tabular}

Table 5. TABLE OF RATING \& AMOUNT OF RAW MATERIAL AVAILABILITY

\begin{tabular}{cc}
\hline \hline Rating & Value \\
\hline Enough & 2 \\
\hline Less & 1 \\
\hline Blank & 0 \\
\hline
\end{tabular}


INTENSIF, Vol.4 No.2 August 2020

ISSN: 2580-409X (Print) / 2549-6824 (Online)

DOI: https://doi.org/10.29407/intensif.v4i2.14321

Table 6. Table Of Rating \& Value Of Criteria Availability Of Packaging

FACILITIES

\begin{tabular}{cc}
\hline \hline Rating & Value \\
\hline Enough & 2 \\
\hline Less & 1 \\
\hline Blank & 0 \\
\hline
\end{tabular}

Table 7. TABLE OF RATING \& VALUE OF HUMAN RESOURCES AVAILABILITY

\begin{tabular}{cc}
\hline \hline Rating & Value \\
\hline Exist & 1 \\
\hline Nothing & 0 \\
\hline
\end{tabular}

Table 8. TABLE OF RATING \& AMOUNT OF PRODUCTION NEEDS CRITERIA

\begin{tabular}{cc}
\hline \hline Rating & Value \\
\hline $1^{\text {st }}$ Highest & 3 \\
\hline $2^{\text {nd }}$ highest & 2 \\
\hline $3^{\text {rd }}$ highest & 1 \\
\hline $4^{\text {th }}$ highest & 0 \\
\hline
\end{tabular}

Table 4 to 8 gives the value for each criterion based on data from the results of discussions with informants and then enter a rating for each criterion.

f. Rating each criterion can be seen in table 9 .

Table 9. TABLE OF RATING CRITERIA

\begin{tabular}{cccccccc}
\hline \hline Machine & Item Name & $\begin{array}{c}\text { Finish } \\
\text { Good } \\
\text { Status }\end{array}$ & $\begin{array}{c}\text { Stock } \\
\text { Raw } \\
\text { Material }\end{array}$ & $\begin{array}{c}\text { Stock } \\
\text { Means of } \\
\text { Packaging }\end{array}$ & $\begin{array}{c}\text { Stock } \\
\text { Man } \\
\text { power }\end{array}$ & $\begin{array}{c}\text { Product } \\
\text { needs. } \\
\text { (Hour) }\end{array}$ & Priority \\
\hline A36 & $\begin{array}{c}\text { Cover Front } \\
\text { Lower Assy } \\
\text { K59J }\end{array}$ & Minus & Enough & Less & Exist & 9.7 & 1 \\
\hline A36 & $\begin{array}{c}\text { Garnish } \\
\text { Front K59A }\end{array}$ & Normal & Enough & Enough & Exist & 8.5 & 3 \\
\hline A36 & $\begin{array}{c}\text { Cover Center } \\
\text { K59A }\end{array}$ & Minus & Less & Blank & Exist & 2.3 & 2 \\
\hline A36 & $\begin{array}{c}\text { Garnish } \\
\text { Front K59A } \\
\text { R-364R }\end{array}$ & Critical & Blank & Enough & No & 8.4 & 4 \\
\hline
\end{tabular}

In table 9, this rating is obtained based on data from PC staff informants obtained each rating on each criterion then enter the values of meals $4-8$, which will be explained in the next table. 
INTENSIF, Vol. No.2 August 2020

ISSN: 2580-409X (Print) / 2549-6824 (Online)

DOI: https://doi.org/10.29407/intensif.v4i2.14321

g. Replace the rating with the value described in table 8 before, as follows.

Table 10. Table Of Total Criteria Value

\begin{tabular}{ccccccccc}
\hline \hline Machine & Item Name & $\begin{array}{c}\text { Finish } \\
\text { Good } \\
\text { Status }\end{array}$ & $\begin{array}{c}\text { Stock } \\
\text { Raw } \\
\text { Material }\end{array}$ & $\begin{array}{c}\text { Stock Means } \\
\text { of } \\
\text { Packaging }\end{array}$ & $\begin{array}{c}\text { Stock } \\
\text { Man } \\
\text { power }\end{array}$ & $\begin{array}{c}\text { Product } \\
\text { Need } \\
\text { (Hour) }\end{array}$ & $\begin{array}{c}\text { Total } \\
\text { Value }\end{array}$ & Priority \\
\hline A36 & $\begin{array}{c}\text { Cover Front } \\
\text { Lower Assy } \\
\text { K59J }\end{array}$ & 3 & 2 & 1 & 1 & 4 & 11 & 1 \\
\hline A36 & $\begin{array}{c}\text { Garnish Front } \\
\text { K59A }\end{array}$ & 1 & 2 & 2 & 1 & 3 & 9 & 2 \\
\hline A36 & $\begin{array}{c}\text { Cover Center } \\
\text { K59A }\end{array}$ & 3 & 1 & 0 & 1 & 1 & 6 & 3 \\
\hline A36 & $\begin{array}{c}\text { Garnish Front } \\
\text { K59A R- } \\
\text { 364R }\end{array}$ & 2 & 0 & 2 & 0 & 2 & 6 & 4 \\
\hline
\end{tabular}

From table 10, we get the following order of production recommendations for the Lower Assy Front Cover K59J to P1 (Priority 1), Garnish Front K59A to P2 (Priority 2), Cover Center K59A to P3 (Priority 3), Garnish Front K59A R-364R to P4 (Priority 4).

h. Calculate the total waiting time of each item to be produced in equation 1 [3].

$$
\begin{aligned}
& \text { Total Waiting Time }(\mathrm{TWT})=\mathrm{P} 1+\mathrm{P} 2+\mathrm{P} 3+\mathrm{P} 4 \\
& \qquad \mathrm{TWT}=0+9.7+20.5+18.2=48.4 \text { hours }
\end{aligned}
$$

i. Calculating the average waiting time of goods for products obtained from the quotient between the total waiting time and the number of priorities can be seen in equation 2 [3].

$$
\begin{gathered}
\text { Average Waiting Time }(\mathrm{AWT})=\mathrm{TWT} / \mathrm{Pn} \\
\mathrm{AWT}=48.4 / 4=12.1 \text { hours }
\end{gathered}
$$

The following is an overview of the production schedule obtained from the information system for selecting the order of production of injection plastic goods on the A36 machine using the priority scheduling method, in picture 3 .

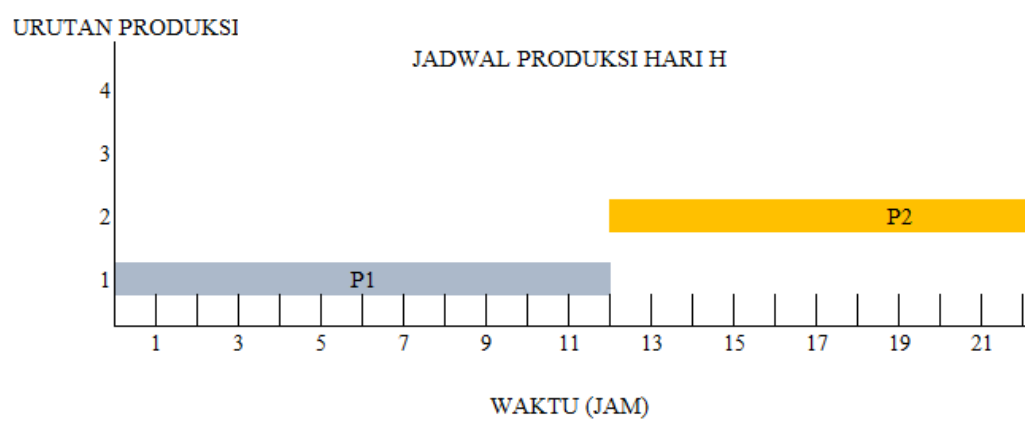

Figure 2. Picture Of MACHINE A63 PRoduction Schedule 
INTENSIF, Vol.4 No.2 August 2020

ISSN: 2580-409X (Print) / 2549-6824 (Online)

DOI: https://doi.org/10.29407/intensif.v4i2.14321

In figure 2 shows the first order for production is the Lower Assy Front Cover K59J (P1) for 12.1 hours starting at 00.00 - 12.06 then transferring to Garnish Front K59A (P2) from 12.07 - 24.12, due to the productive hours of work during only 21 hours a day later the remaining hours of production continue to the next day, as Figure 3.

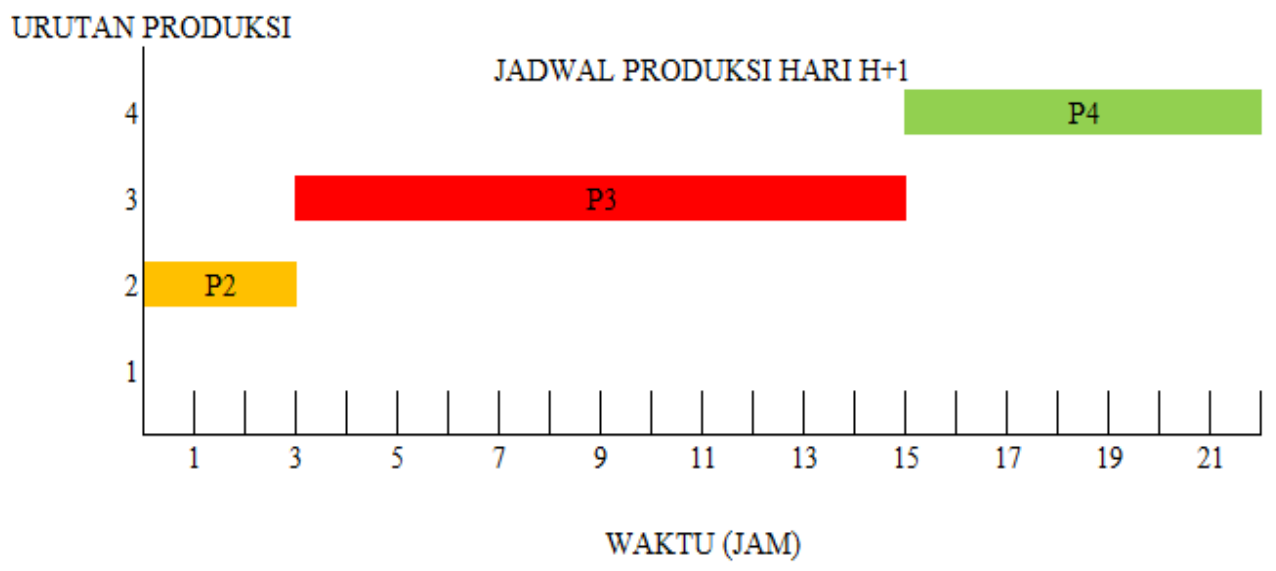

Figure 3. Production Schedule For THE NEXT DAY A36

In picture 3 illustrates the continuation of the previous item for 3.2 hours, from 00.00 03.12 followed by K59A Cover Center goods (P3) from 03.13 - 15.18 and finally, K59A R-364R (P4) Garnish Front goods which will be continued to the next day and so on with the sequence of producing products that have been obtained in table 10.

\section{User Analysis}

For the needs of the design of this information system has six users who will operate the system, namely:

a. PC staff (Production Control) has the task to enter production planning data, data on the needs of packaging facilities, raw materials, human resources and receive data on the availability of packaging facilities, raw materials, human resources.

b. Warehouse Staff must enter the status of an excellent finish in the form of critical, regular and over information.

c. The Matkom staff enters raw material availability data and receives data on raw material requirements.

d. Sarana Packaging staff enter data on the availability of packaging facilities for production needs and receive data on the needs of packaging facilities. Mold Shop staff receive the dandori schedule that has been made and enter the actual dandory hour data that has been carried out according to the table. 
INTENSIF, Vol. No.2 August 2020

ISSN: 2580-409X (Print) / 2549-6824 (Online)

DOI: https://doi.org/10.29407/intensif.v4i2.14321

e. The Production Leader enters data on human resources availability and receives information on human resources needs that have been created.

B. Use Case Identification

Table 11. USE CASE IDENTIFICATION

\begin{tabular}{|c|c|c|c|}
\hline No & Functional & Information & Actor \\
\hline 1 & Login & $\begin{array}{l}\text { Check the validity and authorization of the } \\
\text { user }\end{array}$ & All User \\
\hline 2 & $\begin{array}{l}\text { Production Planning } \\
\text { Data Input }\end{array}$ & $\begin{array}{l}\text { Enter production planning data that has been } \\
\text { made }\end{array}$ & Staff $P C$ \\
\hline 3 & $\begin{array}{l}\text { Input Data Status FG } \\
\text { (Finish Good) }\end{array}$ & $\begin{array}{l}\text { Entering finish good availability data in the } \\
\text { form of quantity of injection plastic goods in } \\
\text { the warehouse }\end{array}$ & Staff Warehouse \\
\hline 4 & $\begin{array}{l}\text { Data Input Raw } \\
\text { Material Availability }\end{array}$ & $\begin{array}{l}\text { Entering raw material data for production } \\
\text { purposes in the way of the number of raw } \\
\text { material available on the matkom }\end{array}$ & Matkom Staff \\
\hline 5 & $\begin{array}{l}\text { Input Data Means of } \\
\text { Packaging }\end{array}$ & $\begin{array}{l}\text { Entering data on the availability of packaging } \\
\text { facilities in the form of quantity of packaging } \\
\text { facilities in packaging facilities }\end{array}$ & $\begin{array}{c}\text { Sarana } \\
\text { Packaging Staff }\end{array}$ \\
\hline 6 & $\begin{array}{l}\text { Data Input Manpower } \\
\text { Availability }\end{array}$ & $\begin{array}{l}\text { Enter quantitative data on the number of human } \\
\text { resources available for production }\end{array}$ & Leader Products \\
\hline 7 & $\begin{array}{l}\text { Data Input Needs for } \\
\text { Packaging Facilities }\end{array}$ & $\begin{array}{l}\text { Entering data for packaging facility needs for } \\
\text { products obtained from the dandory schedule } \\
\text { will then be prepared by the packaging facility } \\
\text { staff }\end{array}$ & Staff PC \\
\hline 8 & $\begin{array}{l}\text { Input Data Needs for Raw } \\
\text { Materials }\end{array}$ & $\begin{array}{l}\text { Entering data on raw material facility } \\
\text { requirements for products obtained from the } \\
\text { dandory schedule will then be prepared by the } \\
\text { matkom staff }\end{array}$ & Staff PC \\
\hline 9 & $\begin{array}{l}\text { Data Input Manpower } \\
\text { Needs }\end{array}$ & $\begin{array}{l}\text { Entering data human resources requirements for } \\
\text { products derived from the dandory table will } \\
\text { then be made by the production leader }\end{array}$ & Staff PC \\
\hline 10 & $\begin{array}{l}\text { Dandori Clock Actual } \\
\text { Confirmation Data Input }\end{array}$ & $\begin{array}{l}\text { Enter the actual data of dandory hours that are } \\
\text { carried out by mould shop staff }\end{array}$ & Staff Moldshop \\
\hline
\end{tabular}

In table 11 describes the functions available in the system according to user needs obtained from the context diagram, the next step is to make use case identification that will define the system requirements. 
INTENSIF, Vol.4 No.2 August 2020

ISSN: 2580-409X (Print) / 2549-6824 (Online)

DOI: https://doi.org/10.29407/intensif.v4i2.14321

C. Use Case Diagram

Use case diagram functions describe briefly between the actors in the system and the tasks in the order created like the following picture.

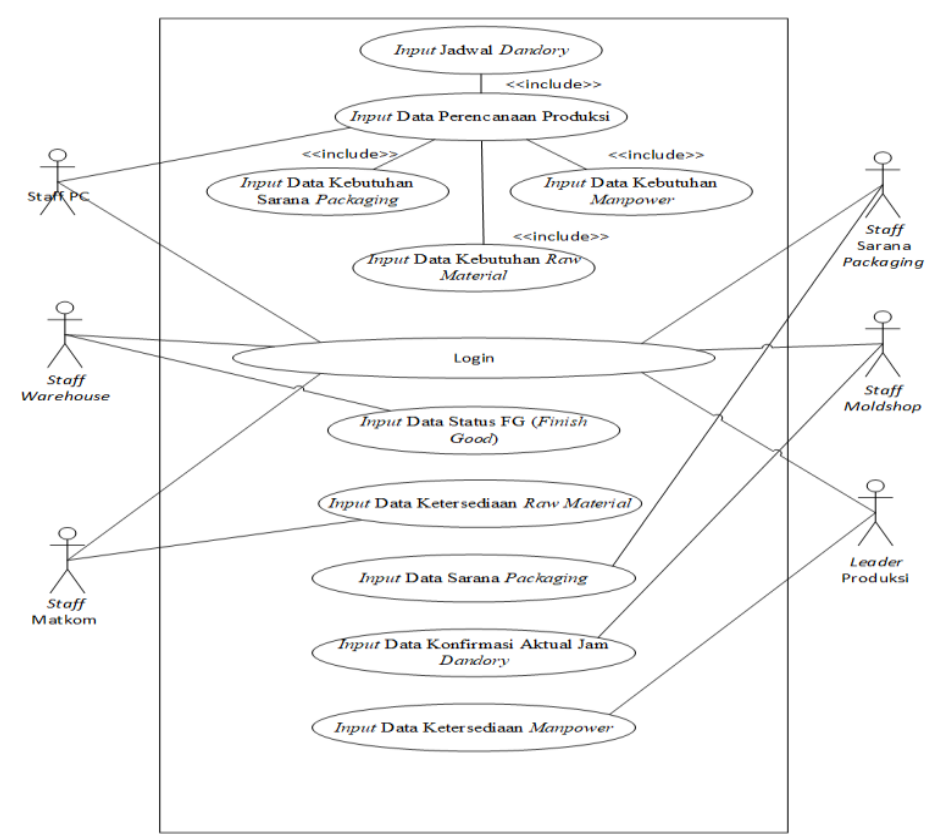

Figure 7. USE CASE DIAGRAM

Figure 7 is a picture of the use of case identification to facilitate the development of functions that exist on the system.

D. Activity Diagram

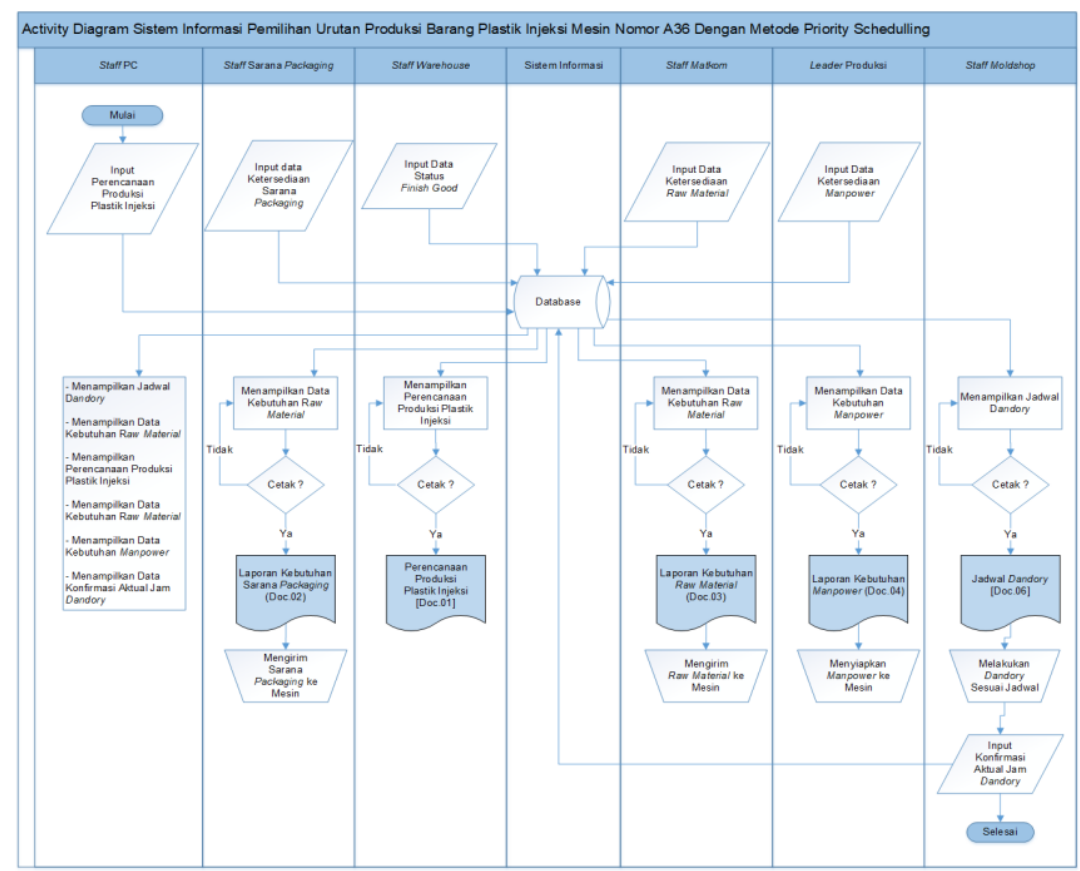

Figure 8. ACTIVITY DIAGRAM 
INTENSIF, Vol. No.2 August 2020

ISSN: 2580-409X (Print) / 2549-6824 (Online)

DOI: https://doi.org/10.29407/intensif.v4i2.14321

Figure 8 explains the relationship between the user and the system connected to the database that can meet the needs of the user by performing computerized calculations to minimize human error.

E. Class Diagram

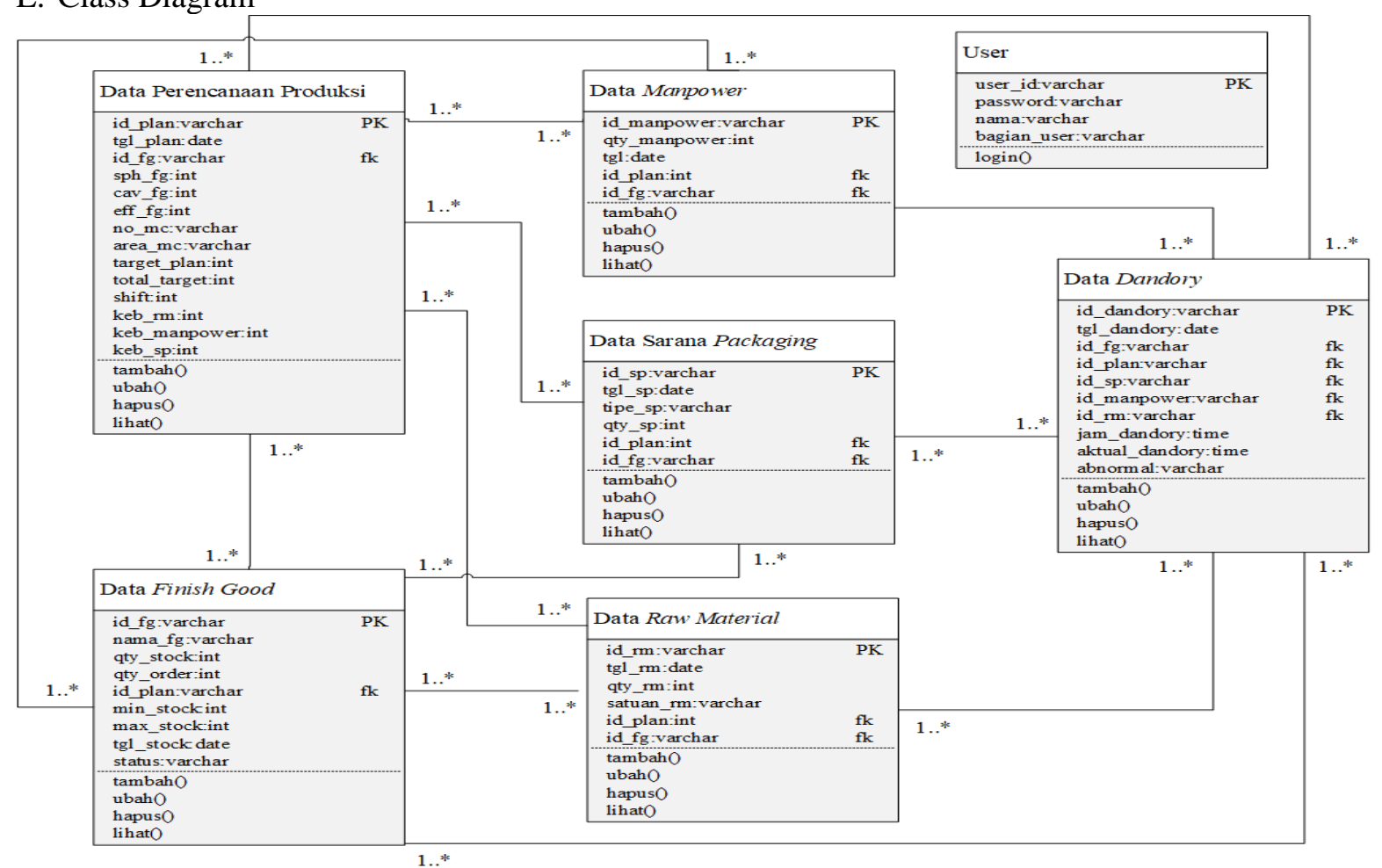

Figure 9. CLASS DiAGRAM

In Figure 9 defines the attributes of a system and describe the methods/functions that exist in the relations system between tables.

F. Hasil Pengujian

Table 12. BLACK-Box Testing Results

\begin{tabular}{|c|c|c|c|c|c|}
\hline No. & Action & $\begin{array}{c}\text { Testing } \\
\text { Scenarios } \\
\end{array}$ & $\begin{array}{c}\text { Expected } \\
\text { Results } \\
\end{array}$ & Testing Result & Information \\
\hline 1 & Login & $\begin{array}{l}\text { Enter your } \\
\text { registered } \\
\text { username and } \\
\text { password }\end{array}$ & $\begin{array}{l}\text { Displays the } \\
\text { home page }\end{array}$ & $\begin{array}{l}\text { Home page } \\
\text { display }\end{array}$ & Valid \\
\hline
\end{tabular}


Table 12. Black-Box Testing Results [CONTINUE]

\begin{tabular}{|c|c|c|c|c|c|}
\hline No. & Action & $\begin{array}{c}\text { Testing } \\
\text { Scenarios }\end{array}$ & $\begin{array}{c}\text { Expected } \\
\text { Results }\end{array}$ & Testing Result & Information \\
\hline \multirow{5}{*}{2} & \multirow{5}{*}{$\begin{array}{l}\text { Input } \\
\text { Production } \\
\text { Planning Data }\end{array}$} & $\begin{array}{l}\text { Enter daily } \\
\text { injection plastic } \\
\text { of production } \\
\text { planning data }\end{array}$ & $\begin{array}{l}\text { Displays daily } \\
\text { injection plastic } \\
\text { of production } \\
\text { planning data }\end{array}$ & $\begin{array}{l}\text { The array of } \\
\text { daily injection } \\
\text { plastic } \\
\text { production } \\
\text { planning }\end{array}$ & Valid \\
\hline & & $\begin{array}{l}\text { Entering data } \\
\text { needs for } \\
\text { packaging } \\
\text { facilities for } \\
\text { daily } \\
\text { production }\end{array}$ & $\begin{array}{l}\text { Displays data } \\
\text { on the needs of } \\
\text { packaging } \\
\text { facilities for } \\
\text { daily } \\
\text { production }\end{array}$ & $\begin{array}{l}\text { Display } \\
\text { packaging } \\
\text { needs for daily } \\
\text { production }\end{array}$ & Valid \\
\hline & & $\begin{array}{l}\text { Enter raw } \\
\text { material data } \\
\text { requirements } \\
\text { for daily } \\
\text { production }\end{array}$ & $\begin{array}{l}\text { Displays data } \\
\text { on raw material } \\
\text { requirements } \\
\text { for daily } \\
\text { production }\end{array}$ & $\begin{array}{l}\text { Display raw } \\
\text { material } \\
\text { requirements } \\
\text { for daily } \\
\text { production }\end{array}$ & Valid \\
\hline & & $\begin{array}{l}\text { Enter the data } \\
\text { human } \\
\text { resources needs } \\
\text { for daily } \\
\text { production }\end{array}$ & $\begin{array}{l}\text { Displays data } \\
\text { on human } \\
\text { resources needs } \\
\text { for daily } \\
\text { production. }\end{array}$ & $\begin{array}{l}\text { Display human } \\
\text { resources need } \\
\text { for daily } \\
\text { production. }\end{array}$ & Valid \\
\hline & & $\begin{array}{l}\text { Enter the } \\
\text { dandory } \\
\text { schedule }\end{array}$ & $\begin{array}{l}\text { Displays } \\
\text { dandory } \\
\text { schedules for } \\
\text { daily } \\
\text { production }\end{array}$ & $\begin{array}{l}\text { Display } \\
\text { dandory } \\
\text { schedule }\end{array}$ & Valid \\
\hline 3 & $\begin{array}{l}\text { Input Data } \\
\text { Status FG } \\
\text { (Finish Good) }\end{array}$ & $\begin{array}{l}\text { Enter the } \\
\text { finished goods } \\
\text { status data } \\
\text { (Finish Good) } \\
\text { regularly }\end{array}$ & $\begin{array}{l}\text { Displays data } \\
\text { on finished } \\
\text { goods status } \\
\text { (Finish Good) } \\
\text { daily }\end{array}$ & $\begin{array}{l}\text { Display the } \\
\text { status of } \\
\text { finished goods } \\
\text { (Finish Good) } \\
\text { daily }\end{array}$ & Valid \\
\hline 4 & $\begin{array}{l}\text { Data Input Raw } \\
\text { Material } \\
\text { Availability }\end{array}$ & $\begin{array}{l}\text { Enter raw } \\
\text { material } \\
\text { availability data } \\
\text { daily }\end{array}$ & $\begin{array}{l}\text { Displays raw } \\
\text { material } \\
\text { availability data } \\
\text { regularly }\end{array}$ & $\begin{array}{l}\text { Display raw } \\
\text { material } \\
\text { availability } \\
\text { daily }\end{array}$ & Valid \\
\hline 5 & $\begin{array}{l}\text { Input Data } \\
\text { Means of } \\
\text { Packaging }\end{array}$ & $\begin{array}{l}\text { Enter data } \\
\text { availability of } \\
\text { packaging } \\
\text { facilities daily }\end{array}$ & $\begin{array}{l}\text { Displays data } \\
\text { availability of } \\
\text { packaging } \\
\text { facilities } \\
\text { regularly }\end{array}$ & $\begin{array}{l}\text { Display the } \\
\text { availability of } \\
\text { packaging } \\
\text { facilities daily }\end{array}$ & Valid \\
\hline
\end{tabular}


Table 12. Black-Box Testing Results [CONTINUE]

\begin{tabular}{|c|c|c|c|c|c|}
\hline No. & Action & $\begin{array}{c}\text { Testing } \\
\text { Scenarios }\end{array}$ & $\begin{array}{c}\text { Expected } \\
\text { Results }\end{array}$ & Testing Result & Information \\
\hline 6 & $\begin{array}{l}\text { Data Input } \\
\text { Manpower } \\
\text { Availability }\end{array}$ & $\begin{array}{l}\text { Enter human } \\
\text { resources } \\
\text { availability data } \\
\text { daily }\end{array}$ & $\begin{array}{l}\text { Displays human } \\
\text { resources } \\
\text { availability data } \\
\text { daily }\end{array}$ & $\begin{array}{l}\text { Display human } \\
\text { resources } \\
\text { availability } \\
\text { daily }\end{array}$ & Valid \\
\hline 7 & $\begin{array}{c}\text { Dandory Clock } \\
\text { Actual } \\
\text { Confirmation } \\
\text { Data Input }\end{array}$ & $\begin{array}{l}\text { Enter the actual } \\
\text { confirmation data } \\
\text { for dandory hours } \\
\text { according to } \\
\text { schedule }\end{array}$ & $\begin{array}{l}\text { Displays the real } \\
\text { confirmation data } \\
\text { of dandory hours } \\
\text { according to } \\
\text { schedule }\end{array}$ & $\begin{array}{l}\text { The dandory } \\
\text { hour's actual } \\
\text { confirmation } \\
\text { display is on } \\
\text { schedule }\end{array}$ & Valid \\
\hline
\end{tabular}

In Figure 12, system testing uses the black box method to test the system's functionality in the software to meet the appropriate and desired results.

\section{CONCLUSION}

From the results of the discussion of this study, it can be concluded that the selected information system for the production of injection plastic goods on the A36 machine using the priority scheduling method produces recommendations for the order of creation of products as follows Front Cover Lower Assy K59J to P1 (Priority 1), Garnish Front K59A to P2 (Priority 2), K59A Cover Center becomes P3 (Priority 3), Garnish Front K59A R-364R becomes P4 (Priority 4) with each production time of 12.1 hours so that it will move goods in the A36 machine more orderly and precise. The test results using a black box that has shown the system can meet the needs of PC staff users. Based on the results of the research, getting an information system can provide recommendations for items that will be produced appropriately in advance. The next system development is by adding planning features for one full month and based on Android so that it can be controlled from each smartphone.

\section{REFERENCES}

[1] A. Mulyanto and A. Haris, "Penerapan Metode Fuzzy Tsukamoto Untuk Menentukan Jumlah Jam Overtime Pada Produksi Barang di PT Asahi Best Base Indonesia ( ABBI ) Bekasi Abstrak,” Inform. SIMANTIK, vol. 1, no. 1, pp. 1-11, 2016, [Online]. Available: http://jurnal.stmikcikarang.ac.id/index.php/Simantik/article/viewFile/1/1.

[2] R. Nurhayati, I. Ma, and R. I. Hartanti, "Penilaian Human Error Probability dengan Metode Human Error Assessment and Reduction Technique ( HEART ) ( Studi di Departemen Finishing PT . Eratex Djaja , Tbk ) Assessment of Human Error Probability with Human Error Assessment and Reduction Technique Me," J. Pustaka Kesehatan, Vol. 5, (No. 3), vol. 5, no. 3, pp. 565-571, 2017. 
[3] A. M. Simarmata and M. Harahap, "Sistem Penjadwalan Iklan Menggunakan Metode Priority Schedulling pada PT . Kidung Indah Selaras Suara ( Radio Kiss FM ) untuk Efektivitas dan Efisiensi Produksi Siaran,” vol. 3, pp. 66-76, 2019.

[4] A. Pramana, R. Watrianthos, and I. Purnama, "Sistem Informasi Pendaftaran Mahasiswa Baru Berbasis Android,” J. Inform. Upgris, vol. 5, no. 2, pp. 121-125, 2019, doi: 10.26877/jiu.v5i2.3807.

[5] E. Febriyanto, U. Rahardja, A. Faturahman, and N. Lutfiani, "Sistem Verifikasi Sertifikat Menggunakan Qrcode pada Central Event Information,” Techno.Com, vol. 18, no. 1, pp. 50-63, 2019, doi: 10.33633/tc.v18i1.2078.

[6] R. A. Sahulata, F. J. Kaunang, D. Y. L. Worotikan, and D. Y. C. Tuwaidan, "Aplikasi Pemilihan Fakultas di Universitas Klabat Bagi Calon Mahasiswa Menggunakan Metode DSS Fuzzy," CogITo Smart J., vol. 4, no. 1, p. 131, 2018, doi: 10.31154/cogito.v4i1.109.131-147.

[7] N. Nuraisyah, I. Permana, and F. N. Salisah, "Sistem Penjadwalan Otomatis Tempat Khutbah Jum'At Mubaligh,” J. Ilm. Rekayasa dan Manaj. Sist. Inf., vol. 3, no. 1, pp. 5964, 2017, [Online]. Available: http://ejournal.uinsuska.ac.id/index.php/RMSI/article/view/3127.

[8] T. M. Octaviano, N. Br, F. Satrya, and F. Kusumah, "Rancang Bangun Monitoring Job Order Dengan Metode Shortest Job First P Ada Cv . Mug Bogor,” pp. 714-723, 2018.

[9] N. A. Popy Meilina, Nurvelly Rosanti, "Sistem Pendukung Keputusan Penentuan Jumlah Produksi Barang Dengan Metode Fuzzy Tsukamoto Berbasis Android," Fak. Tek. Univ. Muhammadiyah Riau, no. November, pp. 1-11, 2017.

[10] A. Sanusi, "Sistem Pendukung Keputusan Dengan Metode Fuzzy SAW Untuk Penilaian Kinerja Dosen Politeknik Harapan Bersama Tegal," Skripsi, Fak. Ilmu Komput., vol. 1, no. 1, pp. 1-6, 2015.

[11] L. Sumaryanti and N. Nurcholis, "Analysis of Multiple Criteria Decision Making Method for Selection the Superior Cattle," INTENSIF J. Ilm. Penelit. dan Penerapan Teknol. Sist. Inf., vol. 4, no. 1, pp. 131-141, 2020, DOI: 10.29407/intensif.v4i1.13863.

[12] D. H. Kusuma, M. Nur Shodiq, and I. Kurnia Fitriani, "Parallel Class Ranking Model Using Analytic Hierarchy Process With Multi Criteria," INTENSIF J. Ilm. Penelit. dan Penerapan Teknol. Sist. Inf., vol. 4, no. 1, pp. 90-107, 2020, doi: 10.29407/intensif.v4i1.13769.

[13] I. Ananda and E. Zuraidah, "Perancangan Sistem Informasi Penjualan Barang Pada PT Asia Truk Pratama Jakarta," J. Inform., vol. 6, no. 2, pp. 193-200, 2019, doi: 10.31311/ji.v6i2.6248.

[14] A. Kristanto, Perancangan Sistem Informasi dan Aplikasinya (Edisi Revisi). Yogyakarta: Gava Media, 2018.

[15] Munawar, Analisis Perancangan Sistem Berorientasikan Objek dengan UML (Unified Modeling Language). Bandung: Informatika, 2018.

[16] P. Hidayatullah and J. K. Kawistara, Pemograman Web. Bandung. Bandung: Informatika, 2015.

[17] N. B. Ginting et al., "Menggunakan Metode Prototype Dan Pengujian Black Box ( Studi Kasus : Fakultas Teknik Dan Sains Universitas Ibn Khaldun ),” vol. 10, no. 2, pp. 577588, 2019.

[18] D. H. Kusuma, D. Yusuf, L. Saadah, T. Informatika, and P. N. Banyuwangi, "Si-Bidan: Sistem Informasi Kesehatan Ibu dan Anak," vol. 3, no. 1, pp. 43-53, 2019.

[19] S. I. Akuntansi and U. B. Sarana, "Siremis : Sistem Informasi Rekam Medis Puskesmas Kecamatan Matraman Jakarta," vol. 3, no. 2, pp. 116-129, 2019.

[20] R. A. Sukamto and M. Shalahuddin, Rekayasa Perangkat Lunak Terstruktur dan Berorientasi Objek. Bandung: Informatika, 2016. 